EESTI NSV TEADUSTE AKADEEMIA TOIMETISED, 25. KOIDE KEEMIA * GEOLOOGIA 1976, Nr. 4

ИЗВЕСТИЯ АКАДЕМИИ НАУК ЭСТОНСКОИ ССР. ТОМ 25 ХИМИЯ * ГЕОЛОГИЯ. 1976, № 4

\title{
СИНТЕЗ АЛКИЛАМИНОЭТИЛСУЛЬФОНАТОВ
}

Алкиламиноэтилсульфонаты (натриевые соли алкилтаурина) можно использовать как моющие вещества $\left[{ }^{1-3}\right]$. Соединения такого типа обладают кроме моющего также водосмягчающим действием и являются диспергаторами. Натриевые соли алкилтаурина термически устойчивы, их биологическая разрушаемость аналогична биологической разрушаемости линейных алкилбензолсульфонатов. Технологический процесс их получения не разработан. Данные о связи между поверхностно-активными свойствами и структурой веществ такого типа в литературе отсутствуют.

Первым этапом настоящего исследования был выбор оптимального метода синтеза и практическое осуществление его для получения индивидуальных соединений типа $\mathrm{RNHCH}_{2} \mathrm{CH}_{2} \mathrm{SO}_{3} \mathrm{Na}$ и $\mathrm{R}\left(\mathrm{CH}_{3}\right) \mathrm{NCH}_{2} \mathrm{CH}_{2} \mathrm{SO}_{3} \mathrm{Na}$, где $\mathrm{R}=\mathrm{C}_{8}-\mathrm{C}_{12}$.

Алифатические алкиламиноэтилсульфонаты могут быть получены разными способами $\left[^{2-6}\right]$. Хорошим методом является синтез ноэтилсульфонатов путем конденсации натриевой соли таурина с алкилгалогенидом.

Алкилтаурин в нейтральной среде ( $\mathrm{pH} \mathrm{6-7)}$ существует в виде внутренней соли $\stackrel{+}{\mathrm{N}} \mathrm{H}_{2} \mathrm{CH}_{2} \mathrm{CH}_{2} \mathrm{SO}_{3}$. Алкилтаурины почти нерастворимы в холодной воде, и благодаря этому свойству их легко выделить из реакционной смеси. В настоящем исследовании для сравнения выхода продуктов и их чистоты проведены параллельно синтезы алкилтауринов и их натриевых солей.

\section{Экспериментальная часть}

\section{Синтез $\boldsymbol{н - а л к и л т а у р и н о в ~}$}

В трехгорлой колбе с мешалкой, термометром и обратным холодильником в $96 \%$-ном этаноле $(100 \mathrm{M \Omega})$ растворяли $0,3 \mathrm{M}$ едкого натра. $\mathrm{K}$ раствору при перемешивании добавляли $0,3 M$ таурина. Образовавшийся осадок растворяли нагреванием в 150 мл $65 \%$-ного этанола. К полученному спирто-водному раствору натриевой соли таурина добавляли $0,1 M$ алкилгалогенида и кипятили 18 . После охлаждения реакционную смесь разбавляли 180 мл 43\%-ного этанола, затем экстрагировали гексаном $(80 \mu \Omega)$ и нейтрализовали $15 \%$-ной $\mathrm{H}_{2} \mathrm{SO}_{4}$ до $\mathrm{pH}$ 6. Осадок фильтровали в горячем виде, высушивали, и алкилтаурин выделяли этанолом. Полученный из спиртового раствора осадок после охлаждения фильтровали и обрабатывали бензолом, при этом растворялись дипроизводные [6], а моноалкилтаурины не растворялись. Синтезированные алкил-

3 ENSV TA Toimetised, $\mathrm{K} * \mathrm{G} 41976$ 
таурины представляли собой белые блестящие порошки. Выход и характеристика их приведены в табл. 1. Дипроизводные алкилтауринов получали в малых количествах. Октилтаурин получили с небольшим выходом. Причиной этого было увеличение растворимости алкилтауринов в $96 \%$-ном этаноле с уменьшением длины алкильного радикала.

Таблица 1

Выход и элементарный состав $\boldsymbol{H}$-алкилтауринов

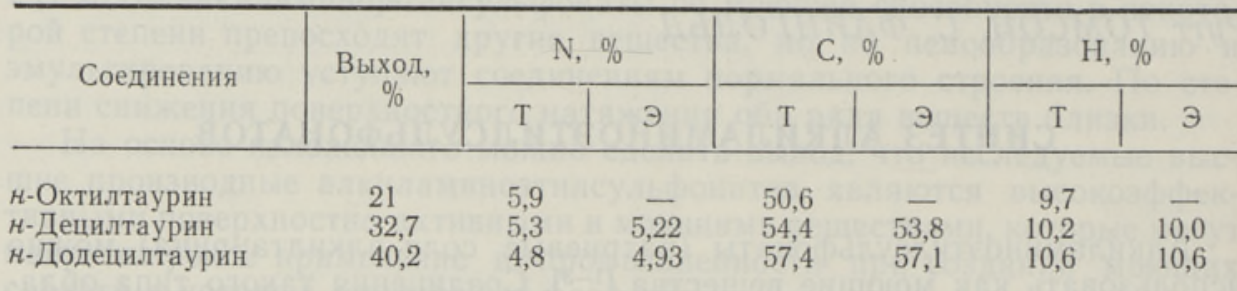

П р и ме чан и е. Т - теоретические, Э - экспериментальные данные.

Таблица 2

Выход и элементарный состав Na-солей $k$-алкилтауринов

\begin{tabular}{|c|c|c|c|c|c|c|c|}
\hline \multirow{2}{*}{$\mathrm{Na}$-соль } & \multirow{2}{*}{$\begin{array}{c}\text { Выход. } \\
\%\end{array}$} & \multicolumn{2}{|c|}{$\mathrm{N}, \%$} & \multicolumn{2}{|c|}{ C, $\%$} & \multicolumn{2}{|c|}{$\mathrm{H}, \%$} \\
\hline & & $\mathrm{T}$ & $\ni$ & $\mathrm{T}$ & 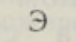 & $\mathrm{T}$ & $\partial$ \\
\hline $\begin{array}{l}\text { Октилтаурина } \\
\text { Децилтаурина } \\
\text { Додецилтаурина (без }\end{array}$ & $\begin{array}{l}74,2 \\
63,2\end{array}$ & $\begin{array}{l}5,43 \\
4,87\end{array}$ & $\begin{array}{l}4,99 \\
4,52\end{array}$ & $\begin{array}{l}46,4 \\
50,2\end{array}$ & $\begin{array}{l}44,7 \\
48,4\end{array}$ & $\begin{array}{l}8,5 \\
9,1\end{array}$ & $\begin{array}{l}7,9 \\
8,9\end{array}$ \\
\hline $\begin{array}{l}\text { перекристаллизации } \\
96 \% \text {-ным этанолом) } \\
\text { Додецилтаурина }\end{array}$ & $\begin{array}{l}69,5 \\
52,7\end{array}$ & $\begin{array}{l}4,44 \\
4,44\end{array}$ & $\begin{array}{l}4,48 \\
4,53\end{array}$ & $\begin{array}{l}53,3 \\
53,3\end{array}$ & $\begin{array}{l}52,6 \\
53,7\end{array}$ & $\begin{array}{l}9,5 \\
9,5\end{array}$ & $\begin{array}{l}9,3 \\
9,6\end{array}$ \\
\hline
\end{tabular}

П р и ме чан и е. Т - теоретические, $Э-$ экспериментальные данные.

\section{Синтез Na-солей алкилтауринов}

B качестве примера приводится синтез Na-соли додецилтаурина. При синтезе $\mathrm{Na-coлей} \mathrm{алкилтауринов} \mathrm{исходили} \mathrm{из} \mathrm{таурина,} \mathrm{соответствующую}$ $\mathrm{Na-coль} \mathrm{готовили} \mathrm{в} \mathrm{реакционной} \mathrm{колбе} \mathrm{на} \mathrm{первом} \mathrm{этапе} \mathrm{реакции.} \mathrm{NaOH}$ растворяли в $96 \%$-ном этаноле ( 1 M NaOH в 330 мл этанола). Полученный раствор нагревали до $50^{\circ} \mathrm{C}$, медленно при перемешивании добавляли $1 M$ таурина и нагревали при этой же температуре в течение $30 \mathrm{muн}$. Для растворения осадка добавляли 500 мл 65\%-ного этанола. Использование в качестве растворителя воды не дало положительных результатов. К полученному спирто-водному раствору (77\%) натриевой соли таурина добавляли $0,33 \mathrm{M}$ додецилбромида, смесь нагревали до кипения и кипятили в течение 18 ; рН раствора 9. Затем реакционную смесь охлаждали до комнатной температуры и для экстрагирования разбавляли гексаном. Количество и концентрация раствора, из которого извлекались неомыляемые соединения, имели большое значение для проведения экстракции, так как полученные Na-соли алкилтауринов в некоторой мере растворялись в гексане. Удовлетворительные результаты получены при $62 \%$-ной концентрации спирто-водного раствора (1930 мл) при этом остался лишь небольшой нерастворимый осадок (1,18\% от взятого таурина). Коли- 


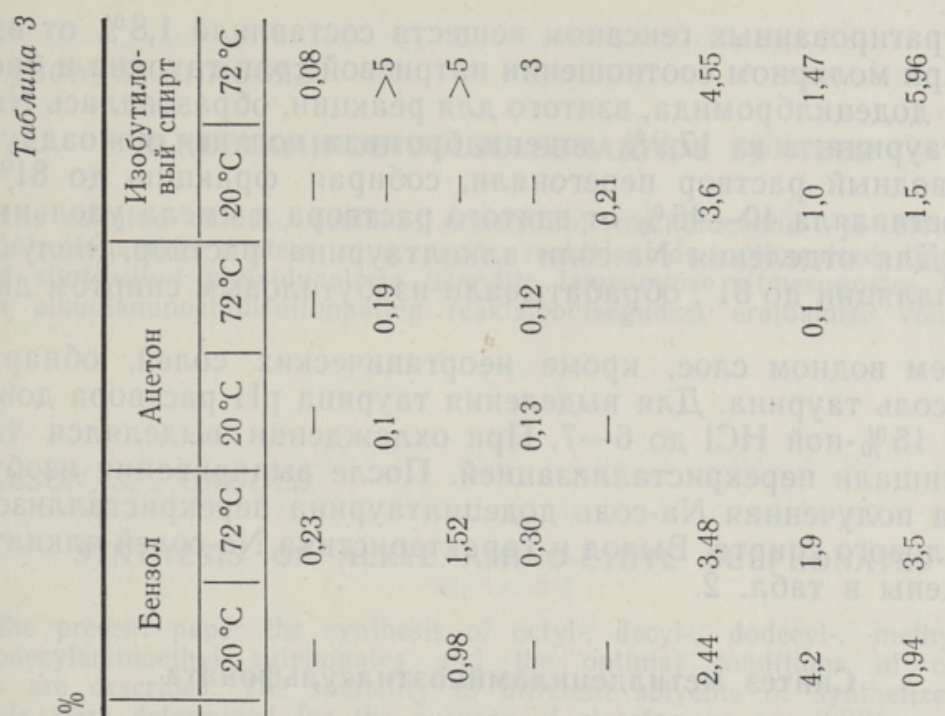

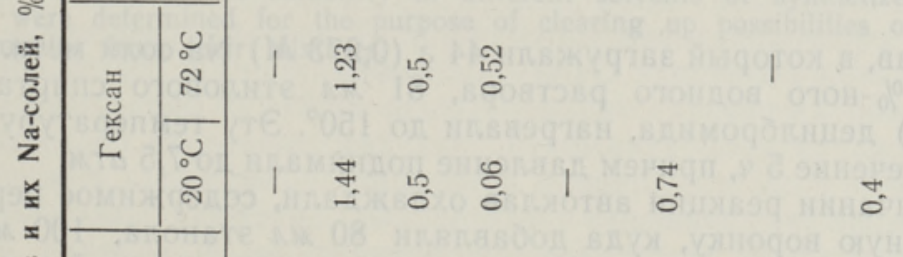

产

敢

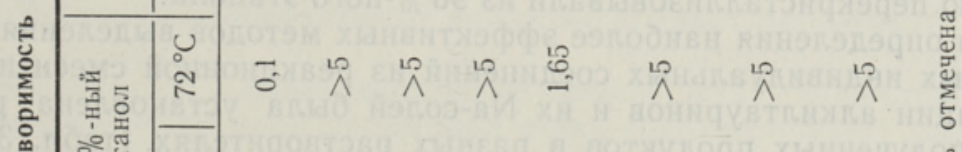

こ

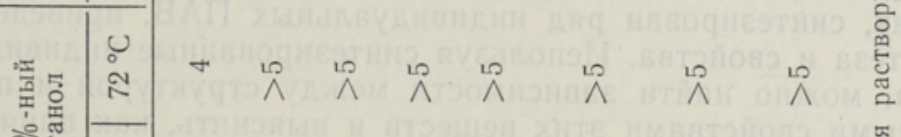

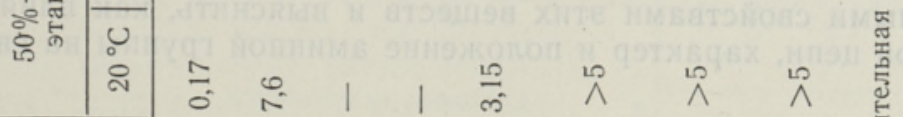

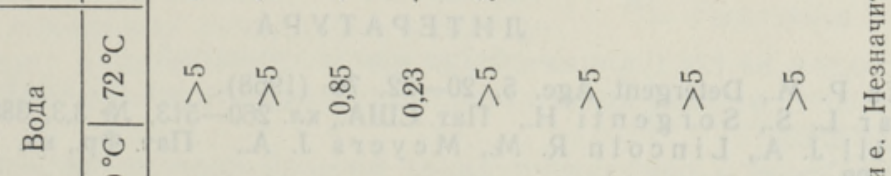

\begin{tabular}{l|l}
0 & 0 \\
0 & 0
\end{tabular}

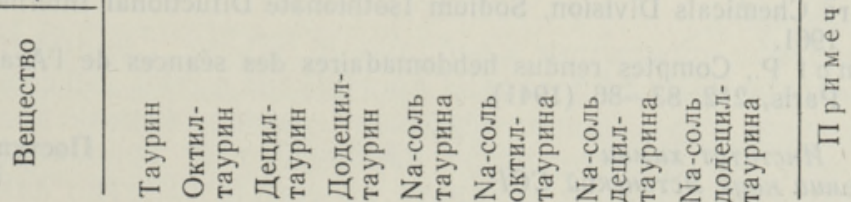


чество экстрагированных гексаном веществ составляло 1,8\% от взятого бромида. При молярном соотношении натриевой соли таурина и бромида $1: 1$ из $72 \%$ додецилбромида, взятого для реакции, образовалась Na-соль дидодецилтаурина, а из 17,9\% додецилбромида получен моноаддукт.

Спирто-водный раствор перегоняли, собирая фракцию до $81^{\circ}$. Эта фракция составляла $40-45 \%$ от взятого раствора и имела удельный вес $0,83-0,84$. Для отделения $\mathrm{Na-coли} \mathrm{алкилтаурина} \mathrm{раствор,} \mathrm{полученный}$ после дистилляции до $81^{\circ}$, обрабатывали изобутиловым спиртом дважды по 350 мл.

В нижнем водном слое, кроме неорганических солей, обнаружена натриевая соль таурина. Для выделения таурина $\mathrm{pH}$ раствора доводили с помощью $15 \%$-ной $\mathrm{HCl}$ до 6-7. При охлаждении выделялся таурин, который очищали перекристаллизацией. После выпаривания изобутилового спирта полученная $\mathrm{Na-coль} \mathrm{додецилтаурина} \mathrm{перекристаллизовыва-}$ лась из этилового спирта. Выход и характеристика $\mathrm{Na-coлей} \mathrm{алкилтаури-}$ нов приведены в табл. 2.

\section{Синтез метилдециламиноэтилсульфоната}

Автоклав, в который загружали 44 г $(0,273 M)$ Na-соли метилтаурина в виде $65 \%$-ного водного раствора, 81 мл этилового спирта и 31 г $\left(0,14\right.$ моль) децилбромида, нагревали до $150^{\circ}$. Эту температуру поддерживали в течение 5 ч, причем давление поднимали до 7,5 aтм.

По окончании реакции автоклав охлаждали, содержимое переносили в делительную воронку, куда добавляли 80 мл этанола, 100 м воды, 80 мл гексана и взбалтывали. Слой гексана отделяли, а слой вода-этанол экстрагировали еще раз гексаном (30 мл) и высушивали досуха.

Реакционную смесь растворяли в 200 мл воды и экстрагировали изобутиловым спиртом четырежды по $80 \mathrm{~m}$. Из слоя изобутилового спирта после испарения растворителя получали Na-соль метилдецилтаурина, которую перекристаллизовывали из $96 \%$-ного этанола.

Для определения наиболее эффективных методов выделения синтезированных индивидуальных соединений из реакционной смеси и методов рафинации алкилтауринов и их $\mathrm{Na}$-солей была установлена растворимость полученных продуктов в разных растворителях (табл. 3). Хорошими растворителями (для отделения таурина от алкилтаурина) являются вода и этиловый спирт.

Итак, синтезирован ряд индивидуальных ПАВ, приведена методика их синтеза и свойства. Используя синтезированные индивидуальные вещества, можно найти зависимости между структурой и поверхностноактивными свойствами этих веществ и выяснить, как влияет длина алкильной цепи, характер и положение аминной группы на свойства ПАВ.

\section{Л И ТЕРА Т У Р А}

1. Pitts P. M., Detergent Age, 5, 20-22, 70 (1968).

2. B it a r L. S., S orgenti H., Пат. США., кл. 260-513, № 3,3, 388.154.

3. Cahill J. A., L incoln R. M., Me yers J. A., Пат. Фр., кл. СIId, № 1. 557. 528.

4. Д жильбер т Э. Е., Сульфирование органических соединений, 1969.

5. Antara Chemicals Division, Sodium Isothionate Difuctional Intermedionate, New York, 1961.

6. Rum p f P., Comptes rendus hebdomadaires des séances de l'Academie des Sciences, Paris, 212, 83-86 (1941). 
Rutt TOMSON, S. FAINGOLD

\section{ALKUULAMINOETUULSULFONAATIDE SUNTEES}

Artiklis esitatud oktüül-, detsüül-, dodetsüül-, metüüldetsüül- ja metüüldodetsüülaminoetüülsulfonaatide süntees ning nende reaktsioonide optimaalsed tingimused. On määratud sünteesitud individuaalsete ühendite lahustuvus mitmesugustes lahustites, et selgitada alküülaminoetüülsulfonaatide reaktsioonisegudest eraldamise võimalusi.

Rutt TOMSON, S. FAINGOLD

\section{SYNTHESIS OF ALKYL AMINO-ETHYL SULPHONATES}

In the present paper the synthesis of octyl-, decyl-, dodecyl-, methyldecyl- and methyldodecylaminoethyl sulphonates and the optimal conditions of corresponding reactions are described. The solubility in different solvents of synthetized individual compounds were determined for the purpose of clearing up possibilities of separating alkyl sulphonates from their mixtures. 